\title{
Artificial infestation of Boophilus microplus in beef cattle heifers of four genetic groups
}

\author{
Ana Mary da Silva ${ }^{1}$, Maurício Mello de Alencar ${ }^{2}$, Luciana Correia de Almeida Regitano ${ }^{2}$, \\ Márcia Cristina de Sena Oliveira $^{2}$ and Waldomiro Barioni Júnior ${ }^{2}$ \\ ${ }^{1}$ Department of Genetics and Evolution, UFSCar, São Carlos, SP, Brazil. \\ ${ }^{2}$ Embrapa Pecuária Sudeste, São Carlos, SP, Brazil.
}

\begin{abstract}
Resistance of beef cattle heifers to the cattle tick Boophilus microplus was evaluated by artificial infestation of 66 beef cattle heifers of the following genetic groups: 16 Nelore (NE), 18 Canchim $x$ Nelore $(\mathrm{CN}), 16$ Angus $x$ Nelore (AN) and 16 Simmental $x$ Nelore (SN). The animals, with a mean age of 16.5 months, were maintained with no chemical tick control in a Brachiaria decumbens pasture. Four artificial infestations with 20,000 B. microplus larvae were carried out 14 days apart and from day 18 to day 22 of each infestation the number of engorged female ticks $(\geq 4.5 \mathrm{~mm})$ was counted on the left side of each heifer. Data were analyzed as the percentage of return ( $P R=$ percentage of ticks counted relative to the number infested), transformed to $(P R)^{1 / 4}$, and as $\log _{10}\left(C_{i j}+1\right)$, in which $C_{i j}$ is the number of ticks in each infestation, using the least squares method with a model that included the effects of genetic group (GG), animal within $G G$ (error a), infestation number (I), GG x I and the residual (error b). Results indicated a significant $G G \times$ I interaction, because $A N$ and $S N$ heifers had a higher percentage of return than $C N$ and $N E$ heifers, while CN heifers showed a higher percentage of return than the NE heifers only in infestations 3 and 4 . Transformed percentages of return were $\mathrm{NE}=0.35 \pm 0.06, \mathrm{AN}=0.89 \pm 0.06, \mathrm{CN}=0.54 \pm 0.05$ and $\mathrm{SN}=0.85 \pm 0.06$.
\end{abstract}

Key words: beef cattle, crossbred, tick resistance.

Received: May 16, 2006; Accepted: January 22, 2007.

\section{Introduction}

The cattle tick Boophilus microplus is an external parasite present in tropical and subtropical areas of America, Africa, Asia and Australia (Leal et al., 2003). Tick parasitism is one of the most detrimental environmental factors affecting cattle production and performance because it causes immunosuppression in the affected cattle (Jonsson, 2006). In both beef and dairy herds the main damage caused by cattle ticks are the costs involved with chemical products and equipment used for parasite control along with losses in fertility, body weight and milk production, although other important losses include leather depreciation due to tick puncture marks and the transmission of infectious diseases, principally Anaplasma and Babesia (Seifert et al., 1968; Gugliemone, 1995; Wambura et al., 1998; Gonçalves et. al., 1999). Furthermore, the indiscriminate use of chemical products may affect future parasite control as a consequence of the development of resistance to the active principle used for tick control preparations (Fraga et al., 2003).

Send correspondence to Ana Mary da Silva. Rua Lindolfo Collor n. 26, conj. São João Bairro Engenho do Meio, 50730-600 Recife, PE, Brazil. E-mail: aninha123@yahoo.com.
There are great differences between Bos indicus (Asian) and Bos taurus (European) cattle in regard to their susceptibility to parasitism by cattle ticks, the scientific literature reporting that infestation increases as the proportion of European genes in an animal increases (Lemos et al., 1985). Studies show that, in general, the number of ticks on zebu (B. indicus) cattle and their crossbreds (zebu x European) is significantly less than the number found on European breeds (Johnston and Haydock, 1969; O' Kelly and Spiers, 1976; Utech and Wharton, 1982). In Brazil, several workers have also reported different degrees of tick-resistance in cattle, both among and within breeds (Lemos et al., 1985; Oliveira et al., 1989; Oliveira and Alencar, 1990; Fraga et al., 2003). These breed differences can be used to match the genotype of the animal to their environment and increase the productive efficiency of herds, thereby satisfying the demands of consumers for high-quality products and respect for the environment (Alencar et al., 2005). In fact, crossing $B$. taurus and $B$. indicus breeds has been used in Brazil to rapidly increase the productivity of beef cattle systems, producing adapted cattle of high potential as a consequence of heterosis and complementarity. Therefore, it is necessary to characterize the different crossbreeding 
systems so that producers can make the correct decisions when choosing the breeds and crossbreeding system.

The objective of the study reported in this paper was to evaluate the degree of tick-resistance of beef heifers of different genetic groups when artificially infested with the cattle tick Boophilus microplus, this study being part of a program of characterization and evaluation of crossbreeding systems.

\section{Material and Methods}

\section{Animals}

This study was undertaken at the Brazilian Agricultural Research Corporation (Empresa Brasileira de Pesquisa Agropecuária - Embrapa), Southeast - Embrapa Cattle (SEC) unit, located at $22^{\circ} 01^{\prime} \mathrm{S}, 47^{\circ} 53^{\prime} \mathrm{W}$ near the city of São Carlos in the Brazilian state of São Paulo. The climate of the region is tropical CAw on the Köppen climate classification and in the last 13 years the coldest months were June and July at $18.3{ }^{\circ} \mathrm{C}$, the warmest was February at $23.6^{\circ} \mathrm{C}$, the driest was August with a rainfall of $20 \mathrm{~mm}$ and the wettest was January with a rainfall of $256 \mathrm{~mm}$. These values represent the average values over 13 years.

The heifers investigated were 16 Nelore, 18 Canchim $\mathrm{x}$ Nelore, 16 Angus x Nelore and 16 Simmental x Nelore. These breeds were chosen to participate in a crossbreeding research project because the aim was to produce offspring different in production potential and in environmental adaptive capacity. Nelore (B. indicus) is a white-coated breed which is the most widely raised beef-breed in Brazil. Canchim ( $5 / 8$ Charolais $+3 / 8$ zebu) is a cream-coated synthetic breed formed in Brazil; Angus (B. taurus) is a blackcoated British European breed; and Simmental (B. taurus) is a cream-coated or white and yellow-coated continental European breed. Heifers of all four genetic groups had the same Nelore genetic basis in that they were offspring of Nelore or high grade Nelore dams of the same origin, dams and heifers being maintained on Tanzania grass (Panicum maximum cv Tanzania) pastures up to weaning. The heifers were sired by three Nelore and three Canchim bulls, by natural service, and nine Angus and seven Simmental bulls, by artificial insemination. At the beginning of the experiment, females, born from August to November of 2003, were, on average, 16.5 months old, and were kept in a Brachiaria grass (Brachiaria decumbens) pasture without any kind of tick control.

\section{Ticks and infestation}

Engorged adult female Boophilus microplus ticks were collected from naturally infested cattle at SEC and incubated in a biological oxygen demand (BOD) chamber at $27^{\circ} \mathrm{C} \pm 1{ }^{\circ} \mathrm{C}$ and a humidity of at least $85 \%-86 \%$ to produce eggs. The eggs were harvested from the female ticks on the $15^{\text {th }}$ day of incubation and $1 \mathrm{~g}$ (about 20,000 larvae) aliquots placed in flasks and returned to the BOD chamber un- der the same conditions until hatching. Only flasks in which over $90 \%$ hatching occurred, by visual examination, were used for infestation. All larvae used for infestation were from 15 to 20 days old.

Each heifer was artificially infested with 20,000 larvae on four separate occasions 14 days apart (13 and 27 of January and 10 and 24 of February 2005) by emptying the contents of one flask on the back of each heifer. On the first infestation we counted the number of engorged female ticks ( $\geq 4.5 \mathrm{~mm}$ ) on the left side of each heifer from day 20 to day 22 (three counts), while for the subsequent three infestations the counts were made on days 18 to 22 of each infestation (five counts). The reason why only three counts were made in the first infestation was that it was not possible to do the first two counts. During the experimental period, average daily mean temperature was $23.25^{\circ} \mathrm{C}$ (minimum $18.25^{\circ} \mathrm{C}$, maximum of $28.2^{\circ} \mathrm{C}$ ), average daily relative humidity was $85 \%$ and average daily rainfall was $7 \mathrm{~mm}$. At the end of the experiment the heifers were treated with an acaricide.

\section{Statistical analysis}

Data from the artificial infestations were analyzed as the percentage of return (PR) as given by the percentage of ticks counted relative to the number infested on one side of the heifer for a tick sex ratio of 1:1 male:female, i.e. $\mathrm{PR}_{i j}=400 \mathrm{C}_{i j} / 20,000$, where $i$ is the heifer, $j$ is the number of the infestation $(1, \ldots, 4), 400$ results from 100 (percentage) $\mathrm{x}$ 2 (two tick sexes) $\times 2$ (two sides of the animal), $C_{i j}=\Sigma C_{i j k}$ (where $\Sigma \mathrm{C}_{i j k}$ is the sum of the number of ticks counted (C), $i$ and $j$ are as above and $k$ is the count number $(1, \ldots, 5)$ ), and 20,000 is the number of tick larvae used for each infestation. For analysis, $\mathrm{PR}_{i j}$ was transformed $(\mathrm{T})$ to $\mathrm{PRT}_{i j}=\left(\mathrm{PR}_{i j}\right)^{1 / 4}$ (Oliveira and Alencar, 1987). Since heifers were maintained in pasture after each infestation natural infestation could have occurred and a further data set using a transformed $\mathrm{C}_{i j}$ value, i.e. $\mathrm{CT}_{i j}=\log _{10}\left(\mathrm{C}_{i j}+1\right)$ (Oliveira et al.,1989), was analyzed to confirm results of $\mathrm{PR}_{i j}$. Data $\left(\mathrm{PRT}_{i j}\right.$ and $\left.\mathrm{CT}_{i j}\right)$ were subjected to analysis of variance (ANOVA) by the least squares method with a model that included the effects of genetic group (GG), animal within GG (error a, to test GG), infestation number (I), GG x I and the residual (error b). Results were also expressed as percentage tick-mortality (TM) by subtracting the percentage of return from 100.

\section{Results and Discussion}

A summary of the transformed percentage of return $\left(\mathrm{PRT}_{i j}\right)$ and the transformed tick count $\left(\mathrm{CT}_{i j}\right)$ ANOVA is presented in Table 1. All sources of variation included in the model significantly $(p<0.01)$ affected the traits studied and the model explained about $87 \%$ of the variation in the traits. The least squares means of the $\mathrm{PRT}_{i j}$ and $\mathrm{CT}_{i j}$ values (Table 2) and the untransformed number of ticks $\left(\mathrm{C}_{i j}\right.$, 
Table 1 - Summary of the analyses of variance of transformed percentage of return $\left(\mathrm{PRT}_{i j}\right)$ and transformed number of ticks counted $\left(\mathrm{CT}_{i j}\right)$.

\begin{tabular}{lccc}
\hline \multirow{2}{*}{$\begin{array}{l}\text { Source of } \\
\text { variation }\end{array}$} & \multirow{2}{*}{$\begin{array}{c}\text { Degrees of } \\
\text { freedom }\end{array}$} & \multicolumn{2}{c}{ Mean Squares } \\
\cline { 3 - 4 } & & $\mathrm{PRT}_{i j}{ }^{\mathrm{a}}$ & $\mathrm{CT}_{i j}{ }^{\mathrm{b}}$ \\
\hline Genetic group (GG) & 3 & 4.45 & 77.92 \\
Animal/GG & 62 & 0.23 & 4.01 \\
Infestation & 3 & 1.37 & 23.42 \\
GG x infestation & 9 & 0.21 & 2.97 \\
Resídue & 186 & 0.03 & 0.43 \\
$\mathrm{R}^{2}(\%)$ & & 87 & 88 \\
\hline
\end{tabular}

${ }^{\mathrm{a}}\left(\mathrm{P}_{i j}\right)^{1 / 4} ;{ }^{\mathrm{b}} \log _{10}\left(\mathrm{C}_{i j}+1\right)$.

Figure 1) are given according to genetic group and infestation. Angus x Nelore and Simmental x Nelore heifers were similar and presented higher $\mathrm{PRT}_{i j}$ values than Nelore and Canchim $\mathrm{x}$ Nelore heifers in all four infestations. However, although Nelore and Canchim x Nelore heifers showed similar $\mathrm{PRT}_{i j}$ values in the first two infestations the Nelore heifers showed lower $\mathrm{PRT}_{i j}$ values than Canchim x Nelore heifers in the last two infestations.

Despite the existence of genetic group $\mathrm{x}$ infestation interaction, in all four infestations, 1/2 European $+1 / 2$ Nelore heifers showed higher $\mathrm{PRT}_{i j}$ values than heifers from the other groups. The estimated means were $0.35 \pm 0.06$ for Nelore, $0.54 \pm 0.06$ for Canchim $x$ Nelore, $0.85 \pm 0.06$ for Simmental x Nelore and $0.89 \pm 0.06$ for An-

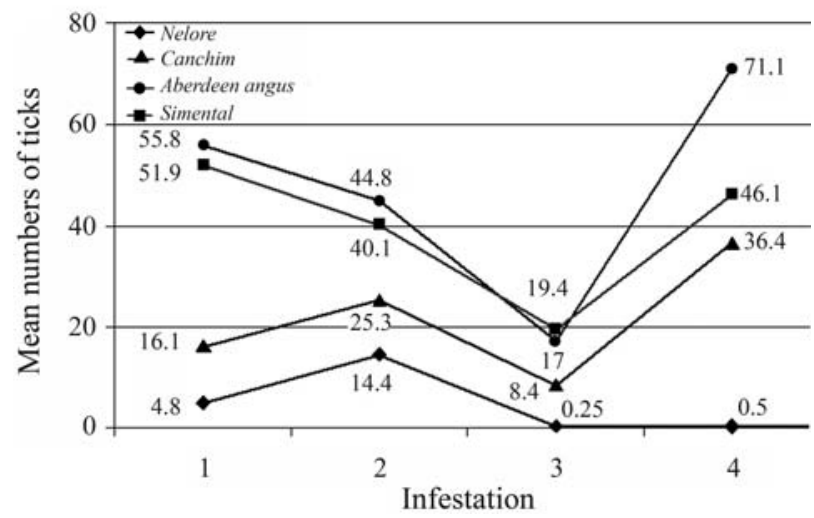

Figure 1 - Mean number of ticks according to infestation and genetic group.

gus x Nelore (Table 2). Hence, Nelore heifers showed the lowest $\mathrm{PRT}_{i j}$ values (i.e. were the most tick-resistant), Canchim x Nelore heifers had intermediate PRT $_{i j}$ values which were higher than Nelore but lower than Angus x Nelore and Simmental x Nelore, and Simmental x Nelore and Angus x Nelore heifers were similar and had the highest PRT $_{i j}$ values. Our data shows that $\mathrm{PRT}_{i j}$ values increased with the proportion of Bos taurus genes in the heifers, and that even the Canchim x Nelore crossbred heifers, which were only $31.25 \%$ European because the Canchim breed is 5/8 Charolais (B. taurus) and 3/8 Zebu (B. indicus), were less resistant than the purebred Nelore heifers. These results support

Table 2 - Least squares means of the transformed percentage of return $\left(\mathrm{PRT}_{i j}\right)$ and transformed number of ticks counted $\left(\mathrm{CT}_{i j}\right)$, according to genetic group and infestation. The $\mathrm{PRT}_{i j}$ standard error (SE) was 0.04 for genetic group $\mathrm{x}$ infestation, 0.02 for infestation and 0.06 for genetic group. The CT $i j \mathrm{SE}$ was 0.16 for genetic group $\mathrm{x}$ infestation, 0.08 for infestation and 0.25 for genetic group.

\begin{tabular}{|c|c|c|c|c|c|}
\hline \multirow[b]{3}{*}{ Cattle genetic group } & \multicolumn{5}{|c|}{$\mathrm{PRT}_{i j}$} \\
\hline & \multicolumn{4}{|c|}{ Infestation } & \multirow[b]{2}{*}{ Overall $^{1}$} \\
\hline & 1 & 2 & 3 & 4 & \\
\hline Nelore & $0.41^{\mathrm{bB}}$ & $0.69^{\mathrm{aB}}$ & $0.09^{\mathrm{cC}}$ & $0.15^{\mathrm{cC}}$ & $0.35^{\mathrm{C}}(0.10)$ \\
\hline Canchim $\mathrm{x}$ Nelore & $0.50^{\mathrm{bB}}$ & $0.71^{\mathrm{aB}}$ & $0.38^{\mathrm{cB}}$ & $0.59^{\mathrm{bB}}$ & $0.54^{\mathrm{B}}(0.43)$ \\
\hline Angus x Nelore & $0.96^{\mathrm{aA}}$ & $0.94^{\mathrm{aA}}$ & $0.70^{\mathrm{bA}}$ & $0.96^{\mathrm{aA}}$ & $0.89^{\mathrm{A}}(0.94)$ \\
\hline Simmental x Nelore & $0.94^{\mathrm{aA}}$ & $0.90^{\mathrm{aA}}$ & $0.68^{\mathrm{bA}}$ & $0.88^{\mathrm{aA}}$ & $0.85^{\mathrm{A}}(0.79)$ \\
\hline \multirow[t]{3}{*}{ Overall } & $0.70^{\mathrm{b}}$ & $0.81^{\mathrm{a}}$ & $0.46^{\mathrm{d}}$ & $0.64^{\mathrm{c}}$ & 0.65 \\
\hline & \multicolumn{5}{|c|}{$\mathrm{CT}_{i j}$} \\
\hline & \multicolumn{4}{|c|}{ Infestation } & \\
\hline Cattle genetic group & 1 & 2 & 3 & 4 & Overall $^{2}$ \\
\hline Nelore & $1.27^{\mathrm{bB}}$ & $2.44^{\mathrm{aB}}$ & $0.17^{\mathrm{CC}}$ & $0.31^{\mathrm{cC}}$ & $1.05^{\mathrm{C}}(4.98)$ \\
\hline Canchim $\mathrm{x}$ Nelore & $1.71^{\mathrm{bB}}$ & $2.54^{\mathrm{aB}}$ & $1.26^{\mathrm{cB}}$ & $2.03^{\mathrm{bB}}$ & $1.89^{\mathrm{B}}(21.54)$ \\
\hline Angus x Nelore & $3.66^{\mathrm{aA}}$ & $3.65^{\mathrm{aA}}$ & $2.48^{\mathrm{bA}}$ & $3.57^{\mathrm{aA}}$ & $3.34^{\mathrm{A}}(47.16)$ \\
\hline Simmental $\mathrm{x}$ Nelore & $3.58^{\mathrm{aA}}$ & $3.48^{\mathrm{aA}}$ & $2.48^{\mathrm{cA}}$ & $3.30^{\mathrm{aA}}$ & $3.21^{\mathrm{A}}(39.37)$ \\
\hline Overall & $2.56^{\mathrm{b}}$ & $3.03^{\mathrm{a}}$ & $1.60^{\mathrm{d}}$ & $2.30^{\mathrm{c}}$ & 2.37 \\
\hline
\end{tabular}

${ }^{1,2}$ Values within parentheses are the estimated means of untransformed percentage return and untransformed number of ticks counted. Different uppercase letters in the same column indicate a significant difference for genetic group within infestation ( $t$-test $\mathrm{p} \leq 0.05$ ). Different lowercase letters in the same line indicate a significant difference for infestation within genetic group ( $\mathrm{t}$-test $\mathrm{p} \leq 0.05$ ). 
those of Oliveira and Alencar (1987), who reported higher $\mathrm{PRT}_{i j}$ values in Canchim than in Nelore cattle. Differences between genetic groups relative to $\mathrm{PRT}_{i j}$ values in artificial infestations have also been reported by Utech et al. (1978) who compared several genetic groups of cattle and found that $B$. indicus Brahman cattle were the most resistant, followed by $B$. indicus $x$ B. taurus crossbreeds and then British $B$. taurus cattle. These authors also reported that among the $B$. taurus breeds studied Jersey heifers were more resistant than Guernsey, Australian Illawarra Shorthorn or Friesian heifers. In naturally infested animals, different degrees of infestation have also been reported in different genetic groups (Lemos et al., 1985; Oliveira et al., 1989; Oliveira and Alencar, 1990). Teodoro et al. (1994) observed a tendency for crossbred cows sired by Jersey bulls to show lower tick infestation than cows sired by Holstein and Brown Swiss bulls, although the differences were not statistically significant. Frisch (1997) classifies B. indicus African and Indian zebu cattle as highly resistant to cattle ticks, $B$. taurus Sanga cattle as a little less resistant, and British and continental B. taurus breeds as having low resistance. It has been suggested that the increased tickresistance of $B$. indicus zebu cattle has evolved because cattle from tropical climates have always been in contact with ticks while $B$. taurus European cattle established contact with ticks only recently when $B$. taurus was introduced into the tropics (Andrade ABF, PhD Thesis, Faculdade de Ciências Agrárias e Veterinárias, UNESP, Jaboticabal, 2001).

Although the exact mechanisms of bovine tick-resistance are still not well known, Riek (1962) has classified them as innate resistance, present before the first infestation, and acquired resistance produced after the first infestation. O'Kelly and Spiers (1976) reported that when first exposed to ticks after birth crossbred zebu calves were more resistant than calves of European breeds, which suggests some degree of innate resistance. Some workers have suggested that the inoculation of foreign substances with the saliva of tick larvae produces irritation which results in self-cleaning (licking, abrading or rubbing) by the animals in an attempt to remove the ectoparasite (Kemp et al., 1976; Koudstaal et al., 1978). Riek (1962) and Willadsen et al. (1978) reported hypersensitive reactions in tick-resistant cattle that may result in ticks dropping off the cattle. Other mechanisms may also be related to tick-resistance, such as arteriovenous anastomosis in the dermal vasculature of $B$. taurus cattle as suggested by Schleger et al. (1981) and mast-cell counts in the skin of taurine and zebuine hosts as reported by Moraes et al. (1992).

In our study, the $\mathrm{PRT}_{i j}$ means for the different infestations were $0.70 \pm 0.02$ for the first infestation, $0.81 \pm 0.02$ for the second infestation, $0.46 \pm 0.02$ for the third infestation and $0.64 \pm 0.02$ for the fourth infestation, showing a significant reduction in the mean $\mathrm{PRT}_{i j}$ value for the third infestation. There was an increase in the $\mathrm{PRT}_{i j}$ and $\mathrm{CT}_{i j}$ values for Nelore and Canchim x Nelore heifers from the first to the second infestation, while Angus $\mathrm{x}$ Nelore and Simmental x Nelore heifers maintained high $\mathrm{PRT}_{i j}$ and $\mathrm{CT}_{i j}$ values in the first and second infestations (Table 2, Figure 1). The increase in the $\mathrm{PRT}_{i j}$ values from the first to the second infestation may, in part, have been due to the number of counts made, three counts having been made in the first infestation and five in the following infestations. In the third infestation, all genetic groups showed low $\mathrm{PRT}_{i j}$ values. In the fourth infestation, there was a significant increase in number of ticks on Canchim x Nelore, Angus x Nelore and Simmental x Nelore heifers, while Nelore heifers maintained a low level of infestation, suggesting that these heifers acquired a stable resistance after the third infestation. Another possibility is that because the heifers in our study were maintained on Brachiaria grass pasture throughout the experiment it is possible that natural infestations occurred and caused part of the variation between infestations. This natural infestation could have originated from preexisting larvae, or larvae remaining from previous artificial infestations, in the paddock the heifers were maintained and/or larvae from neighbor paddocks occupied by other groups of animals. It is also possible that a more pronounced natural infestation occurred between the third and the fourth infestations, when climatic conditions were more favorable to ticks. Tick development between the $2^{\text {nd }}$ and the $3^{\text {rd }}$ counts might have been affected by variations in climatic variables (Figure 2) and this could be the reason for the decrease in number of ticks in the $3^{\text {rd }}$ infestation.

In regard to acquired resistance, Riek (1962) studied $B$. taurus, B. indicus and their crosses and found that although acquired resistance was least apparent in purebred B. taurus there was considerable variation in the degree of resistance between individual cattle within breed groups. Wagland (1975) compared B. indicus Brahman and $B$. taurus Shorthorn cattle during four successive infestations with B. microplus larvae and obtained a similar number of engorged females after the first infestation in both breeds, however, in the fourth infestation Brahman heifers had significantly less engorged females than Shorthorn heifers. In a subsequent study, Wagland (1978) found that Brahman

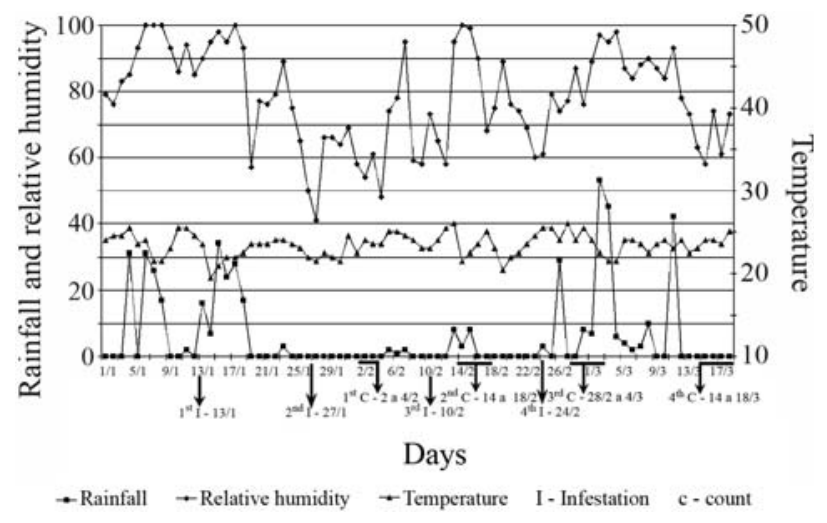

Figure 2 - Relative humidity, temperature and rainfall for January to March 2005. 
Table 3 - Cattle genetic group and number $(\mathrm{N})$ and percentage (\%) of heifers by tick-mortality class.

\begin{tabular}{|c|c|c|c|c|c|c|}
\hline \multirow[b]{3}{*}{ Cattle genetic group } & \multicolumn{6}{|c|}{ Tick-mortality class ${ }^{1}$} \\
\hline & \multicolumn{2}{|c|}{$>99.0 \%$} & \multicolumn{2}{|c|}{$>98.0 \%$ and $\leq 99.0 \%$} & \multicolumn{2}{|c|}{$>97.0 \%$ and $\leq 98.0 \%$} \\
\hline & $\mathrm{N}$. & $\%$ & $\mathrm{~N}$. & $\%$ & $\mathrm{~N}$. & $\%$ \\
\hline Nelore & 16 & 100.00 & - & - & - & - \\
\hline Canchim $x$ Nelore & 15 & 83.33 & 3 & 16.67 & - & - \\
\hline Angus x Nelore & 11 & 68.75 & 3 & 18.75 & 2 & 12.50 \\
\hline Simmental x Nelore & 10 & 62.50 & 5 & 31.25 & 1 & 6.25 \\
\hline
\end{tabular}

${ }^{1}$ Tick-mortality obtained by subtracting the mean percentage of return $\left(\mathrm{PRT}_{i j}\right)$ of the four infestations from 100 .

heifers developed measurable degrees of tick-resistance during the first three days of infestation while Shorthorn heifers develop tick-resistance only after 20 days, indicating that as well as the innate resistance component, which varies among breeds, there is a significant acquired resistance component. Barriga et al. (1993) studied B. microplus infestations of $B$. taurus Hereford cattle but found no relationship between natural resistance and the ability to develop acquired resistance. In Barriga's study, although the cattle were homogeneous in breed, sex, age and maintenance conditions during the first infestation, when the cattle had no previous contact with ticks, distinct resistance groups were established for tick functions such as duration of feeding and the start of egg-laying and hatching. This suggests that cattle belonging to one initial group segregated into distinct groups, supporting an heterogeneous acquired immunological response. High degrees of tickresistance have been associated with zebu cattle and their crossbreeds, probably due to the adaptive ability of such cattle, which, among other aspects, is expressed by coat characteristics, such as the short-hair and smooth-hair traits.

The intraclass correlation (IC), based on the heifer nested within genetic group and the residual components of variance, was used as a measure of the repeatability of the $\mathrm{PRT}_{i j}$ values and was estimated to be $\mathrm{IC}=0.65 \pm 0.05$. This value indicates the correlation between the $\mathrm{PRT}_{i j}$ values of any two infestations and that the first infestation would be $65 \%$ as accurate in estimating the $\mathrm{PRT}_{i j}$ values in the second infestation. We found that the average of all four infestations would be $88 \%$ as accurate in estimating the $\mathrm{PRT}_{i j}$ values in a fifth infestation, representing an increase of $35 \%$ in the accuracy relative to only one measurement. This value of repeatability and the variations observed in the $\mathrm{PRT}_{i j}$ values for the four infestations suggest that more than one infestation should be done when evaluating the resistance of heifers to cattle ticks. The repeatability obtained in this study is higher than the value of 0.29 reported by Fraga et al. (2003) for naturally infested Caracu cattle. This was to be expected because the environmental conditions in our study were more controlled than in natural infestations with long periods between counts during which there can be physiological changes in cattle, climate and pasture.
Utech et al. (1978) divided tick-resistance in cattle into the following tick-mortality (TM) classes: > 98\% TM, highly tick-resistant cattle; $95.1 \%$ to $98 \%$ TM, moderately tick-resistant; $90 \%$ to $95 \%$ TM, low tickresistance; and $<90 \% \mathrm{TM}$, very low tick-resistance. The observed TM based on the mean $\mathrm{PRT}_{i j}$ values of the four infestations (Table 3) shows that a TM above 99\% occurred in the following percentage of heifers: $100 \%$ for Nelore; $83.33 \%$ for Canchim x Nelore; $68.75 \%$ for Angus $\mathrm{x}$ Nelore; and $62.5 \%$ for Simmental x Nelore. Furthermore, about $16.67 \%$ of the Canchim $x$ Nelore heifers were included in the $>98 \%$ to $\leq 99 \%$ TM group, which also included $18.75 \%$ of the Angus x Nelore and $31.25 \%$ of the Simmental x Nelore heifers. Based on the classification of Utech et al. (1978) all (100\%) of the Nelore heifers and the Canchim x Nelore heifers would be considered highly tick-resistant while only $87.5 \%$ of the Angus x Nelore heifers and $93.75 \%$ of the Simmental $x$ Nelore heifers would be considered highly tick-resistant, the remaining percentage of Angus x Nelore heifers (12.5\%) and Simmental x Nelore heifers $(6.25 \%)$ being moderately tickresistant. Since Canchim x Nelore heifers have, on average, a higher proportion of $B$. indicus zebu genes the higher percentage of high tick-resistance shown by these heifers as compared to Angus x Nelore and Simmental x Nelore heifers, with a relatively low percentage of $B$. indicus genes, was to be expected.

Considering all four infestations, Angus x Nelore and Simmental x Nelore heifers showed a higher percentage of tick return than Nelore heifers, while Canchim x Nelore heifers reached an intermediate degree, suggesting higher resistance to cattle tick in Nelore heifers, intermediate resistance in Canchim x Nelore heifers, and lower resistance in Angus x Nelore and Simmental x Nelore heifers. Nevertheless, most of the Angus $\mathrm{x}$ Nelore and Simmental $\mathrm{x}$ Nelore heifers can also be considered highly resistant.

\section{Acknowledgments}

This study was supported by the Brazilian Federal Research Council (Conselho Nacional de Desenvolvimento Científico e Tecnológico - CNPq) 


\section{References}

Alencar MM, Fraga AB and Silva AM (2005) Genotype adaptation to tropical environments: Cattle resistance to horn fly (Haematobia irritans, Linnaeus) and to cattle tick (Boophilus microplus, Canestrini) in diferent cattle genotypes. Agrosci 9:579-585.

Barriga OO, Da Silva SS and Azevedo CSJ (1993) Inhibition and recovery of ticks functions in cattle repeatedly infested with Boophilus microplus repeatedly infested cattle. J Parasitol 79:710-715.

Fraga AB, Alencar MM, Figueiredo LA, Razook AG and Cyrillo JNSG (2003) Análise de fatores genéticos e ambientais que afetam a infestação de fêmeas bovinas da raça Caracu por carrapato (Boophilus microplus). Rev Bras Zootec 32:1578-1586.

Frisch JE (1997) Como críar productivamente ganado de carne en el sub-tropico. In: Congresso Internacional de Transferência Tecnológica Agropecuaria, Assunción, Paraguay. Anais CEA 5:137-162.

Gonçalves PM, Passos LMF and Freitas MFB (1999) Detection of IgM antibodies against Babesia bovis in cattle. Vet Parasitol 82:11-17.

Gugliemone AA (1995) Epidemiology of babesiosis anda anaplasmosis in South and Central America. Vet Parasitol 57:109-119.

Johnston LAY and Haydock KP (1969) The effect of cattle tick (Boophilus microplus) on production of Brahman-cross and British-breed cattle in Northern Australia. Aust Vet J 45:175-179.

Jonsson NN (2006) The productivity effects of cattle tick (Boophilus microplus) infestation on cattle, with particular reference to Bos indicus cattle and theirt crosses. Vet Parasitol 137:1-10.

Kemp DH, Koudstaal D, Roberts JA and Kerr JD (1976) Boophilus microplus: The effect of host resistance on larval attachments and growth. Parasitol 73:123-136.

Koudastaal D, Kemp DH and Kerr JD (1978) Boophilus microplus: Rejection of larvae from British breed cattle. Parasitol 73:123-136.

Leal TA, Freitas JRD and JR. Vaz SI (2003) Perspectives for control of bovine tick. Acta Sci Vet 31:1-11.

Lemos AM, Teodoro RL, Oliveira GP and Madalena FE (1985) Comparative performance of six Holstein-friesian x Guzera grade in Brasil. Burdens of Boophilus microplus under field condition. Anim Prod 41:187-191.

Moraes FR, Moraes JRE, Costa AJ, Rocha UF and Ardisson FA (1992) A comparative study of lesions caused by different parasitic stages of Boophilus microplus (Canestrini) in the skins of naturally infested taurine and zebuine hosts. The correlation of ticks resistance with mast cell counts in the host's skin. Braz J Vet Anim Sci 29:378-383.
O'kelly JC and Spiers WC (1976) Resistance to Boophilus microplus (Canestrini) in genetically different types of calves in early life. J Parasitol 62:312-317.

Oliveira GP and Alencar MM (1987) Resistance of cattle to the tick Boophilus microplus. I Artificial Infestation. Pesq Agropec Bras 22:433-438.

Oliveira GP and Alencar MM (1990) Resistência de bovinos de seis graus de sangue Holandês-guzerá ao carrapato (Boophilus microplus) e ao berne (Dermatobia hominis). Arq Bras Med Vet Zootec 42:127-135

Oliveira GP, Alencar MM and Freitas AR (1989) Resistance of cattle to the tick Boophilus microplus. II. Infestação Natural. Pesq Agropec Bras 24:1267-1271.

Riek RF (1962) Studies end the reaction of animals to infestation with tick. VI. Resistance of cattle to infestation with the tick Boophilus microplus (Canestrini). Aust J Agricult Res 13:532-549.

Seifert GW, Springell PH and Tatchell RJ (1968) Radioactive studies on the feeding of larvae, nymphs and adults of the cattle tick Boophilus microplus (Canestrini). Parasitol 58:414-430.

Schleger AV, Lincoln DR and Bourne AS (1981) Arteriovenous anastomosis in the dermal vasculature of the skin of Bos taurus cattle, and their relationship with resistance to the tick Boophilus microplus. Aust J Biol Sci 34:26-35.

Teodoro RL, Lemos AM and Madalena FE (1994) Carga parasitária de Boophilus microplus em vacas mestiça europeu $\mathrm{x}$ zebu. Rev Soc Bras Zootec 23:223-228.

Utech KBW, Wharton RH and Kerr J D (1978) Resistance to Boophilus microplus (Canestrini) in different breeds of cattle. Aust J Agricult Res 29:885-895.

Utech KBW and Wharton RH (1982) Breeding for resistance to Boophilus microplus in Australian Illawarra Shorthorn and Brahman_x Australian Illawarra Shorthorn cattle. Aust Vet J 58:41-46.

Wagland BM (1975) Host resistance to cattle tick (Boophilus microplus) in Brahman (Bos indicus) cattle. I. Response of previously unexposed cattle to four infestations with 20.000 larvae. Aust J Agricult Res 26:1073-1078.

Wagland BM (1978) Host resistance to cattle tick (Boophilus microplus) in Brahman (Bos indicus) cattle. III. Growth on previously unexposed animal. Aust J Agricult Res 29:401109.

Wambura PN, Gwakisa PS, Silayo RS and Rugaimukamu EA (1998) Breed-associated resistance to tick infestation in Bos indicus and their crosses with Bos taurus. Vet Parasitol 77:63-70.

Willadsen P, Willians PG, Roberts JA and Kerr JD (1978) Response of cattle to allergens from Boophilus microplus. Inst J Parasitol 8:89-95.

Associate Editor: Fábio de Melo Sene 